

\title{
A Review and The Proposed Framework for Digital Technology Addiction and Over-Indebtedness
}

Nur Hafidzah Idris, Fahmi Abdul Rahim, Shafinar Ismail, Nur Taufiqah Idris

To Link this Article: http://dx.doi.org/10.6007/IJARBSS/v11-i11/11597

DOI:10.6007/IJARBSS/v11-i11/11597

Received: 07 September 2021, Revised: 10 October 2021, Accepted: 27 October 2021

Published Online: 16 November 2021

In-Text Citation: (Idris et al., 2021)

To Cite this Article: Idris, N. H., Rahim, F. A., Ismail, S., \& Idris, N. T. (2021). A Review and The Proposed Framework for Digital Technology Addiction and Over-Indebtedness. International Journal of Academic Research in Business and Social Sciences, 11(11), 1053 - 1063.

Copyright: (c) 2021 The Author(s)

Published by Human Resource Management Academic Research Society (www.hrmars.com)

This article is published under the Creative Commons Attribution (CC BY 4.0) license. Anyone may reproduce, distribute, translate and create derivative works of this article (for both commercial and non-commercial purposes), subject to full attribution to the original publication and authors. The full terms of this license may be seen at: http://creativecommons.org/licences/by/4.0/legalcode

Vol. 11, No. 11, 2021, Pg. $1053-1063$

http://hrmars.com/index.php/pages/detail/IJARBSS

JOURNAL HOMEPAGE

Full Terms \& Conditions of access and use can be found at http://hrmars.com/index.php/pages/detail/publication-ethics 


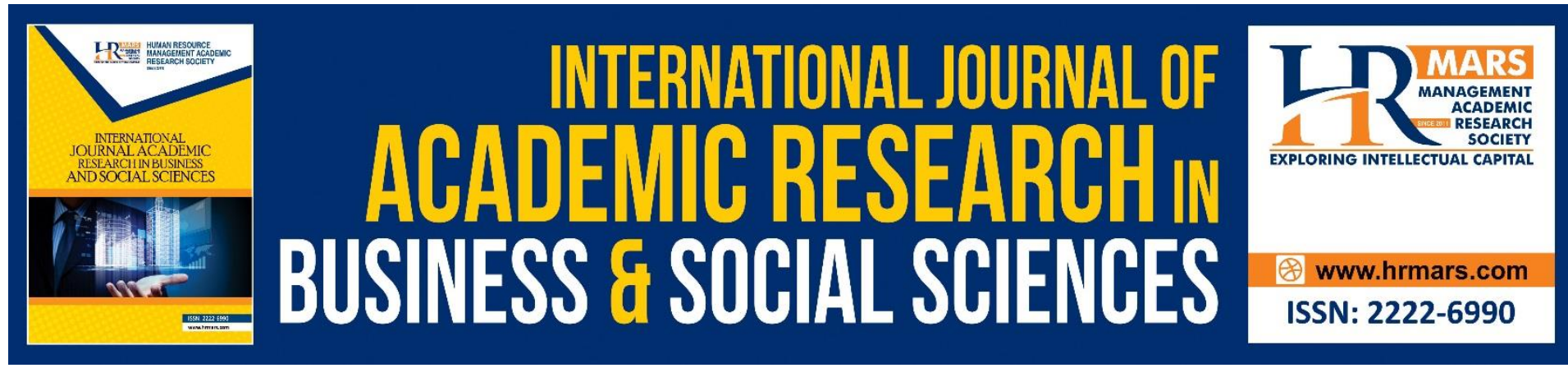

\title{
A Review and The Proposed Framework for Digital Technology Addiction and Over-Indebtedness
}

\author{
Nur Hafidzah Idris, Fahmi Abdul Rahim, Shafinar Ismail, Dr. Nur \\ Taufiqah Idris
}

Faculty of Business Management, UiTM Malaysia, Hospital Orang Asli Gombak, Malaysia

\begin{abstract}
Technology had become an essential part of our daily routine, which we cannot live without. It becomes a useful communications tool where people communicate with each other's in many ways via digital technology. However, the developments in the digital software had caused to the new types of behavioural addiction to arise, such as digital game addiction and Facebook addiction. Moreover, the overuse of the digital technology had a trigger to the situations of fear of missing out (FAMO), where the individual will be trying hard to be at par as his/her social norms. Although previous studies have stated that the over-use and dependency of digital technology effects on individual consumption, however, there is no study has considered the impact of digital technology towards over-indebtedness. With regards to this limitation, thus this study tries to formulate a conceptual model for digital technology addiction and individual over-indebtedness in filling a research gap in the related field.
\end{abstract}

Keywords: Digital Technology, Technology Addiction, Over-Indebtedness, Financial WellBeing, Household Debt

\section{Introduction}

It is fair to say that we are currently live in a credit-centric consumer society in times of rapid technological transition. The spread of digital technologies, especially the smartphone has produced new venues with lower entry barriers and fewer gatekeepers for both purchasing and credit management (Matas, 2015). The Western world has seen a significant increase in mobile technology use in the last decade. In 2016, 93\% of the population owned a smartphone in the UK, and users spend more time accessing the Internet via a phone than through other devices, such as laptops and desktop computers. Whereas the Internet and Smartphone penetration rate in Malaysia for 2017 is $80.1 \%$ and 2020 is $98.2 \%$, and the numbers are expected to increase further. These recent trends support mobiles, and the Internet has become closely interlinked to enable "on-the-go" access to a range of facilities, including web-browsing, communication, shopping, banking, and gaming (Kuss et al., 2018).

Technology has become an essential part of our daily routine, which we cannot live without. It becomes a useful communication tool where people communicate with each other in many ways via digital technology. Moreover, digital technology which is in the 
form of smart phones, web-based television and tablet PCs, is currently changing the world of advertising. More and more people do not only watch commercials on TV but also see advertisements (ads) on their smart phone or tablets. People can play games or watch interactive videos via their gadgets, and generally while browsing the ads will appear on their screens. These will trigger the sense of purchasing among digital technology users and hence lead to spontaneous purchase among users. Besides, the big data collection from the digital technology provides information about the technology users, such as their interest and restore the details information of the users including their account for purchasing payment method. For example, the shopping applications (apps) like Shoppe, 11Sstreet and Lazada granted a facility for buyers to restore their favorite payment tools, especially for credit card users. As the ads appear according to with the user's interest plus with the efficient and easy method for purchasing and paying, these will cause to the high spending among technology users and hence will be trapped with a situation of high debt. The longer the time spends by the users on their technology, the higher the chances of the individual to become a shopping addiction and hence to influence them to have the prodebt attitudes.

The technologies develop the role of the smartphone, i.e. Mobile internet access has completely changed the game over the last five years, and societal norms around credit changes as well as the perception of money and credit (Nanninga et al., 2015). The social media such as Instagram and Facebook leading causes to materialistic among its users, by the purpose of being favourable by the followers, or trying hard to be 'centrality' or accepted among social networks. Furthermore, it is stated that a need for belongingness can make youth susceptible to the influences of a credit-driven culture (Kempson, 2002; Leclerc, 2012; O'Loughlin \& Szmigin, 2006; Palan et al., 2011).

Moreover, it is said that the growth of digital technology that affects buying behaviour leads to the situation of impulsive buying. This impulsiveness also has a strong tendency and the relationship with the debt problem. One possibility is that individuals who act impulsively in their spending decisions use forms of consumer credit, which make them more vulnerable to incurring debt problems (Gathergood \& Weber, 2014)). A recent study revealed one of the more common reasons for payment default for people between 18 and 25 years in Swedish is for invoice purchases and that a large portion of these relates to e-commerce (Larsson et al., 2016)The study shows that e-commerce had led to individuals entering risky financial situations and even over-indebtedness. Besides, the study also found that the smartphone subscription as a problematic "first credit" for their clients. It is more common to have recurring payment problems in the group with more than one mobile subscription ( $10 \%$ of the sample) than those with none or just one.

Having a debt problem such as high debt and default payment are the indicators of over-indebtedness. Presently, there is no consensus in the literature on the definition of over-indebtedness and how to measure it (D’Alessio \& lezzi, 2013; Fatoki, 2015; Hiilamo, 2020; Idris et al., 2018; Schicks, 2014)). The growing knowledge of over-indebtedness mention four general criteria of over-indebtedness, which are: (i) making high repayments relative to income, (ii) being in arrears, (iii) making heavy use of credit and (iv) finding debt as a burden. In general, people are considered over- indebted if they have difficulty in meeting with their financial commitments related to loans or the payment of bills (Disney \& Gathergood, 2013). Over-indebtedness refers, then, to a situation where a person or household does not have enough money and facing with difficulty to pay debt instalments and interests after other necessary paid expenditures (Raijas et al., 2010). 
The heavy use and dependency on digital technology (also referred to addiction) will influence to the adverse outcomes. Previous studies discussed on the consequences of the mobile phone addiction towards mental health, such as depression, addiction and anxiety (Elhai et al., 2017; Nalwa \& Anand, 2003; Rosen et al., 2013). As such, from the best of researcher knowledge in the time of current publications, there is no studies had been conducted in investigating the effects on digital technology addiction towards overindebtedness. With regards to this, therefore the aim of this paper is to proposed a conceptual framework for digital technology addiction and it effect to individual overindebtedness.

\section{Literature Review}

Digital Technology and Technology Addiction

Digital technology is defined as "any technological device that functions through a binary computational code such as mobile phones, tablets, laptops and computers" (Moreira dos Anjos-Santos et al., 2017), and "any information used on a computer or disseminated on a computer is known as digital technology. Digital technology canenhance the level of creativity and distribution of information. Some examples of digital technology are computer programs and software; web pages and websites, including social media; data and databases" (Conway et al., 2016).

Addiction is defined as impulse dependent on a habit of a specific activity or substance use though it has destructive effects on the physical, social, emotional, and mental health of the individual as well as his/her financial situation (Kim et al., 2016). As such, (Billieux et al., 2007) considering exaggerate mobile phone use also viewed as a behaviouraladdiction. Addiction is classified in two ways which are drug addiction and behavioural addiction (Nayak, 2018). According to (Kesici \& Tunç, 2018), here are six criteria to consider behaviour as an addiction which are:

- Salience: That a specific action becomes vital in terms of life.

- Mood modification: That this action affects a person's mood

- Tolerance: The increase in the amount of action to show the same effect on the person.

- Withdrawal: Unpleasant emotions or physical symptoms are seen when the action does not continue or stopsimmediately.

- Conflict: The conflict that a person experiences because of the dilemma between him/her and the people around him/her.

- Relapse: That a certain action tends to occur again after the avoidance or control lasting long years.

\section{The Measurement of Digital Technology Addiction}

In measuring digital technology addiction construct, the researcher had to go thru and review previous studies on technology addictions such as the Internet addiction, Smartphone Addiction, Problematic Usage Mobile Phone (PUMP), Computer Addictions, Online Cognition Scale (OCS), and Facebook Addiction Scale. From it, the researcher had identified that most of the scales measurements have a standard definition; which defines and discuss on the "dependency, over-use on the technology usage", and the withdrawal symptoms from the digital technology addicted. Table 1 among the scale measurements for digital technology addiction by previous studies. 
Table 1: Digital Technology Measurement

\begin{tabular}{|c|c|c|}
\hline Author & Construct & Dimensions/Elements \\
\hline (Kesici \& Tunç, 2018) & $\begin{array}{l}\text { Digital Addiction } \\
\text { Scale }\end{array}$ & $\begin{array}{l}\text { Overuse } \\
\text { While eating my meal, I am occupied with mobile phone, } \\
\text { tablet, orcomputer. } \\
\text { I continuously look at the digital devices (mobile phone or } \\
\text { tablet) in a trip, picnic or social environments where I am } \\
\text { with my friend. } \\
\text { I overuse the digital devices out of their purposes. } \\
\text { I find myself checking my digital devices upon dealing with a } \\
\text { work. } \\
\text { - I deal with the digital devices like tablet even if I do } \\
\text { demand things. } \\
\text { Non-restraint } \\
\text { I cannot control myself on the amount of time of using the } \\
\text { digitaldevices. } \\
\text { I have unsuccessful attempts to reduce the time I spend } \\
\text { with thedigital devices. } \\
\text { - I cannot reduce the time I spend with the } \\
\text { digital devices. Inhibiting the flow of life } \\
\text { The digital devices prevent me from doing my } \\
\text { responsibilitiesrelated to home and school. } \\
\text { I have missed many opportunities because of spending a lot } \\
\text { of timewith the digital devices. } \\
\text { I am unaware of what happens around me when I deal } \\
\text { with the digital devices. } \\
\text { I feel that I become less creative because of using the digital } \\
\text { devices. } \\
\text { Emotional state } \\
\text { Assigning a job to me when I spend time with digital devices } \\
\text { makes me annoyed. } \\
\text { The environments where I cannot use the digital devices bore } \\
\text { anxious. } \\
\text { me. } \\
\text { I feel very unhappy and angry when I do not use my digital } \\
\text { devicesfor a long time. } \\
\text { devices. }\end{array}$ \\
\hline
\end{tabular}




\begin{tabular}{|c|c|c|}
\hline $\begin{array}{l}\text { Elhai, Dvorak, } \\
\text { Levine, \&Hall, 2017; } \\
\text { Kuss, Harkin, Kanjo, } \\
\text { \& Billieux, 2018; } \\
\text { Merlo, Stone, \& } \\
\text { Bibbey, 2013) }\end{array}$ & $\begin{array}{lr}\text { lematic } & \text { Mobile } \\
\text { Phone } & \text { Usage } \\
\text { (PUMP) } & \end{array}$ & $\begin{array}{l}\text { Dependence } \\
\text { I can easily live without my mobile phone * } \\
\text { I feel lost without my mobile phone } \\
\text { It is hard for me to turn my mobile phone off } \\
\text { It is easy for me to spend all day not using my mobile phone } \\
\text { I get irritated when I am forced to turn my mobile phone off } \\
\text { I don't attach a lot of importance to my mobile phone * } \\
\text { - Is it hard for me not to use my mobile phone when } \\
\text { I feel like it } \\
\text { Prohibited use } \\
\text { I don't use my mobile phone when it is completely forbidden } \\
\text { to useit * } \\
\text { I don't use my mobile phone in a library, cinema, or hospital } \\
\text { * I use my mobile phone where it is forbidden to do so } \\
\text { I try to avoid using my mobile phone where people } \\
\text { need silence * } \\
\text { Danger } \\
\text { I have found myself in risky situations because I have used } \\
\text { mymobile phone whilst walking } \\
\text { I use my mobile phone whilst crossing the road } \\
\text { I use my mobile phone in situations that would qualify as } \\
\text { dangerous } \\
\text { I use my mobile phone while driving } \\
\text { I try to avoid using my mobile phone when driving on the } \\
\text { motorway* } \\
\text { *Reversed item }\end{array}$ \\
\hline $\begin{array}{l}\text { (Kim et al., 2016; Y. } \\
\text { H. Lin et al., 2014; } \\
\text { Nayak, 2018; } \\
\text { Samaha \& Hawi, } \\
\text { 2016; Van Deursen, } \\
\text { Bolle, Hegner, \& } \\
\text { Kommers, 2015) } \\
\end{array}$ & $\begin{array}{l}\text { tphone addiction } \\
\text { scale }\end{array}$ & $\begin{array}{l}\text { Compulsive behaviour } \\
\text { Functional impairment } \\
\text { Withdrawal } \\
\text { Tolerance }\end{array}$ \\
\hline$\left(\begin{array}{l}\text { *Meral, 2018; } \\
\text { Nalwa \& Anand, } \\
2003)\end{array}\right.$ & $\begin{array}{l}\text { Internet addiction } \\
\text { scale } \\
\text { *internet } \\
\text { addiction = digital } \\
\text { technology } \\
\text { addiction }\end{array}$ & $\begin{array}{l}\text { Social comfort } \\
\text { I am most comfortable online. } \\
\text { I feel safest when I am on the Internet. } \\
\text { You can get to know a person better on the Internet than in } \\
\text { person } \\
\text { I often find it peaceful to be online. } \\
\text { I can be myself online. } \\
\text { I get more respect online than "in real life." } \\
\text { People accept me for who I am online }\end{array}$ \\
\hline
\end{tabular}




\begin{tabular}{|c|c|c|}
\hline $\begin{array}{l}\text { (Davis, Flett, } \\
\text { Besser, 2002) }\end{array}$ & $\begin{array}{l}\text { \& Problematic } \\
\text { Internet Use }\end{array}$ & $\begin{array}{l}\text { Online relationships can be more fulfilling than offline ones. } \\
\text { I am at my best when I am online. } \\
\text { I wish my friends and family knew how people regard me } \\
\text { online. } \\
\text { The Internet is more "real" than real life. } \\
\text { I say or do things on the Internet that I could never do offline. } \\
\text { - When I am online, I can be } \\
\text { carefree. } \\
\text { Loneliness/depression } \\
\text { Few people love me other than those I know online. } \\
\text { I am less lonely when I am online. } \\
\text { I cannot see myself ever without the Internet for too long. } \\
\text { The Internet is an important part of my life. } \\
\text { I feel helpless when I don't have access to the Internet } \\
\text { I am bothered by my inability to stop using the } \\
\text { Internet so much. } \\
\text { Diminished impulse control } \\
\text { I often keep thinking about something I experienced } \\
\text { online wellafter I have logged off. } \\
\text { When I am on the Internet, I often feel a kind of "rush" or } \\
\text { emotional high. } \\
\text { I use the Internet more than I ought to. } \\
\text { People complain that I use the Internet too much. } \\
\text { I I never stay on longer than I had planned. } \\
\text { When I am not online, I often think about the Internet. } \\
\text { The offline world is less exciting than what you can do online. } \\
\text { I can't stop thinking about the Internet. } \\
\text { Even though there are times when I would like to, I can't cut } \\
\text { down on my use of the Internet. My use of the Internet } \\
\text { Sometimes seems beyond my control. } \\
\text { When I am online I don't think about my responsibilities. } \\
\text { I find that I go online more when I have something else, I } \\
\text { amsupposed to do. }\end{array}$ \\
\hline
\end{tabular}




\section{Over-Indebtedness}

Presently, there is no specific definition of over-indebtedness and how to measures it. Recent studies identify three possible measurements or model of consumer overindebtedness. These are objective measures, subjective measures and administrative measures:

Objective measure: It refers to a quantitative model that defines over-indebtedness to be an unsustainable level of debt regarding their debt ratio. The debt ratio varies from $30 \%$ to $50 \%$. However, most researchers had used $50 \%$ debt ratio as a cutting point in determining consumer over-indebtedness (Marron, 2012; Veliziotis et al., 2010).

Subjective measure: For this model, it defines the over-indebted borrower base on the self-report. The justification is, it is the borrower's himself who knows whether he is in over-indebted on not. A borrower is in an over-indebted situation if he faces with financial difficulties, such as repayment problems, defaults on bills or loan repayments (B ett i et al., 2007; Disney \& Gathergood, 2013; Idris, 2019; Larsson et al., 2016; Lusardi \& Tufano, 2009) Besides from self-reported, there is a recent definition of over-indebtedness introduced by (Gutierrez-Nieto et al., 2017) and (Schicks, 2014). The researchers define over-indebtedness specifically from the consumer's perspective, which is "borrower sacrifices." In this case, an over-indebted person is the one who has to make sacrifices in order to deal with financial difficulties. The sacrifices action like doing overtime work, psychological sacrifices (shameful), and deterioration in basic needs, such as reductions in food intake.

Administrative measure: The measurement that records over-indebted who those cases of non-payments of debt that have been officially registered or declared before a court. Example; in the process of bankruptcy or being declared as bankruptcy and received a warning letter from financial institutions due to the default payment. However, this measurement of over-indebtedness is not widely used in the literate, as bankruptcy and received a warning letter from financial institutions are considers as a last resort of overindebtedness (Fatoki, 2015; Raijas et al., 2010; Schicks, 2013)). However, the administrative measures had been criticized by the previous scholar such as in (Schicks, 2014), due to the reason that it is the late stage of over-indebtedness.

\section{Digital technology addiction and Over-Indebtedness}

Based on the discussions, digital technology addiction refers to individual dependency on the technology usage. The digital technology refers to any technology devices such as smartphone, laptop tab and etc. meanwhile, over-indebtedness can be defined as an individual who is currently facing with a high debt, having a default in loan payment, facing with a payment difficulty. The growing in digital technology along with the increasing trend in household debt and debt burden among individual had become a signal that the digital technology gives effect to individual over-indebtedness.

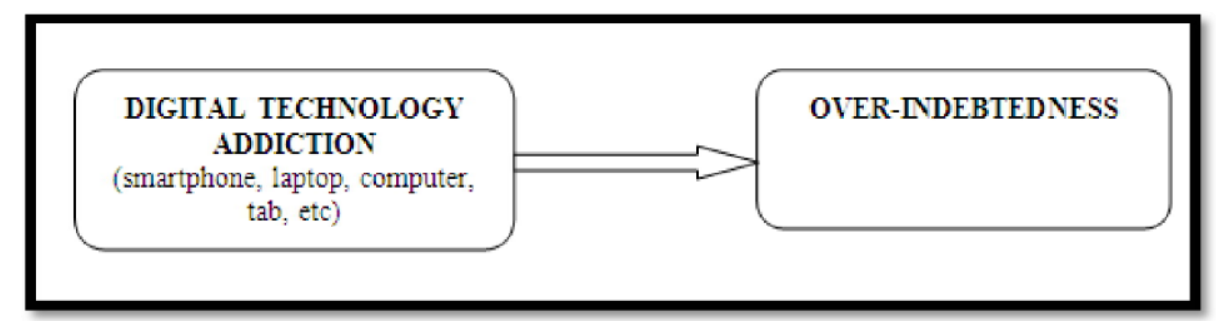

Figure 1: Proposed Framework for Digital Technology Addiction and Over-Indebtedness 


\section{Conclusion}

The technological and economic institutions offer opportunities for growing consumption and credit use and the emergence of credit problems. In general, the most prominently featured research fields in the analysis indicate that research on indebtedness in digital contexts focuses on a systemic perspective rather than a consumer or client perspective. The main concern from the previous studies is on how to develop systems and business strategies to protect business owners from losses incurred from insolvent consumers, rather than to research consumers who have become indebted because of over-consumption in a digital context, and the impact has on their lives. Currently, the consequences of the effect in digital technology for consumption and indebtedness remain under-researched. Noticing that there is a need for a study on this field, therefore this study had come out with a proposed model on digital technology addiction towards individual over-indebtedness As presented in Figure 1, the digital technology addiction refers to any technology tools and the device such as a smartphone, internet, laptop, computer and tab. With details discussions on digital technology addiction and its effect to over-indebtedness, the researcher hopes that this proposed model would be a guideline for the future researcher in exploring a relationship between digital technology and individual overindebtedness, as well as other behavioral financial outcomes in the future.

\section{Corresponding Author}

Nur Hafidzah Idris

Email: nurhafidzahidris@gmail.com

\section{References}

Betti, G., Dourmashkin, N., Rossi, M. C., \& Yin, Y. (2007). Consumer over-indebtedness in the EU: Measurement and characteristics. Journal of Economic Studies, 34(2), 136-156. https://doi.org/http://dx.doi.org/10.1108/01443580710745371

Billieux, J., Linden, M. Van Der, Zermatten, A., D’Acremont, M., \& Ceschi, G. (2007). Does impulsivity relate to perceived dependence on and actual use of the mobile phone? Applied Cognitive Psychology, 21(4), 527-537. https://doi.org/10.1002/acp

Carlsson, H., Larsson, S., Svensson, L., \& Åström, F. (2017). Consumer Credit Behavior in the Digital Context: A Bibliometric Analysis and Literature Review. Journal of Financial Counseling and Planning, 28(1), 76-94. https://doi.org/10.11144/Javeriana.upsy143.oias

Conway, C. S., Harris, S. M., Smith, S., Brackett, V., \& Hayes, G. (2016). Mentoring Students through Digital Learning Experiences. In Handbook of Research on Global Issues in NextGeneration Teacher Education (pp. 206-227). IGI Global. https://doi.org/10.4018/9781-4666-9948-9.ch012

D'Alessio, G., \& lezzi, S. (2013). Household over-indebtedness: definition and measurement with Italian data. In Questioni di Economia e Finanza (No. 149; Occasional Papers).

Disney, R., \& Gathergood, J. (2013). Financial literacy and consumer credit portfolios. Journal of Banking and Finance, 37(7), 2246-2254. https://doi.org/10.1016/j.jbankfin.2013.01.013

Elhai, J. D., Dvorak, R. D., Levine, J. C., \& Hall, B. J. (2017). Problematic smartphone use: A conceptual overview and systematic review of relations with anxiety and depression psychopathology. Journal of Affective Disorders, 207, 251-259.

https://doi.org/10.1016/j.jad.2016.08.030 
Fatoki, O. (2015). The causes and consequences of household over-indebtedness in South Africa. Journal of Social Sciences, 43(2), 97-103.

Gathergood, J., \& Weber, J. (2014). Self-control, financial literacy \& the co-holding puzzle. Journal of Economic Behavior and Organization, 107(Part B), 455-469. https://doi.org/10.1016/j.jebo.2014.04.018

Gutierrez-Nieto, B., Serrano-cinca, C., \& Cuesta-Gonzalez, M. de la. (2017). A multivariate study of over-indebtedness ' causes and consequences. International Journal of Consumer Studies, 41(2), 188-198. https://doi.org/10.1111/ijcs.12324

Hauff, J. C., \& Nilsson, J. (2020). Determinants of indebtedness among young adults : Impacts of lender guidelines, explicit information and financial ( over ) confidence. International Journal of Consumer Studies, 44(2), 89-98. https://doi.org/10.1111/ijcs.12549

Hiilamo, H. (2020). The Legacy of Economic Recession in Terms of Over-Indebtedness : A Framework and Review of the Evidence. Social Policy and Society, 1-14. https://doi.org/10.1017/S1474746420000354

Idris, N. H. (2019). Modelling Digital Technology Addiction for Individual Over-indebtednsss. The International Journal of Science \& Technoledge, 7(2), 75-80. https://doi.org/10.24940/theijst/2019/v7/i2/ST1902-018

Idris, N. H., Wee, M. F., Ismail, S., \& Samad, K. A. (2018). Financial knowledge, debt literacy and over-indebtedness. The Journal of Social Sciences Research, 7(3), 22-29.

Kempson, E. (2002). Over-indebtedness in Britain (Issue September). http://www.pfrc.bris.ac.uk/Reports/Overindebtedness_Britain.pdf

Kesici, A., \& Tunç, N. F. (2018). The Development of the Digital Addiction Scale for the University Students: Reliability and Validity Study. Universal Journal of Educational Research, 6(1), 91-98. https://doi.org/10.13189/ujer.2018.060108

Kim, Y., Jeong, J. E., Cho, H., Jung, D. J., Kwak, M., Rho, M. J., Yu, H., Kim, D. J., \& Choi, I. Y. (2016). Personality factors predicting smartphone addiction predisposition: Behavioral Inhibition and Activation Systems, Impulsivity, and Self-Control. PLOS ONE, 11(8), 1-15. https://doi.org/10.1371/journal.pone.0159788

Kuss, D. J., Harkin, L., Kanjo, E., \& Billieux, J. (2018). Problematic smartphone use: Investigating contemporary experiences using a convergent design. International Journal of Environmental Research and Public Health, 15(1), 142-158. https://doi.org/10.3390/ijerph15010142

Larsson, S., Svensson, L., \& Carlsson, H. (2016). Digital Consumption and Over-Indebtedness Among Young Adults in Sweden. Lund University Internet Institute (LUii).

Leclerc, K. (2012). Influential factors contributing to college student spending habits and credit card debt. Perspectives, 4(1), 149-156. https://scholars.unh.edu/perspectives/vol4/iss $1 / 20$

Lusardi, A., \& Tufano, P. (2009). Debt literacy, financial experiences, and overindebtedness. Journal of Pension Economics and Finance, 14(04), 332-368. https://doi.org/10.1017/

Marron, D. (2012). Producing over-indebtedness. Journal Of Cultural Economy, 5(4), 407-421. https://doi.org/10.1080/17530350.2012.703144

Nalwa, K., \& Anand, A. P. (2003). Internet addiction in students: A cause of concern. CyberPsychology \& Behavior, 6(6), 653-656. https://doi.org/10.1089/109493103322725441

Nanninga, E., Ward, S., \& Hoong, V. (2015). Navigating the New Digital Divide Dutch edition : Digital impact on retail in the Netherlands. 26. 
http://www2.deloitte.com/content/dam/Deloitte/nl/Documents/deloitte-digital/deloitte$\mathrm{nl}$-digital-divide-study-2015.pdf

Nayak, J. K. (2018). Relationship among smartphone usage, addiction, academic performance and the moderating role of gender: A study of higher education students in India. Computers and Education, 123(May), 164-173. https://doi.org/10.1016/j.compedu.2018.05.007

O'Loughlin, D., \& Szmigin, I. (2006). "I'Il always be in debt": Irish and UK student behaviour in a credit led environment. Journal of Consumer Marketing, 23(6), 335-343. https://doi.org/10.1108/07363760610701878

Palan, K. M., Morrow, P. C., Trapp, A., \& Blackburn, V. (2011). Compulsive buying behavior in college students: The mediating role of credit card misuse. The Journal of Marketing Theory and Practice, 19(1), 81-96. https://doi.org/10.2753/MTP1069-6679190105

Raijas, A., Lehtinen, A., \& Leskinen, J. (2010). Over-indebtedness in the Finnish consumer society. Journal of Consumer Policy, 33(3), 209-223. https://doi.org/10.1007/s10603010-9131-8

Rosen, L. ., Whaling, K., Carrier, L. M., Cheever, N. A., \& Rokkum, J. (2013). The Media and Technology Usage and Attitudes Scale: An empirical investigation. Computer in Human Behavior, 29(6), 2501-2511.

Schicks, J. (2013). The sacrifices of micro-borrowers in Ghana - A customer-protection perspective on measuring over- indebtedness. The Journal of Development Studies, 49(9), 1238-1255. https://doi.org/10.1080/00220388.2013.775421

Schicks, J. (2014). Over-indebtedness in microfinance - An empirical analysis of related factors on the borrower level. World Development, 54, 301-324. https://doi.org/10.1016/j.worlddev.2013.08.009

Veliziotis, M., Bryan, M., \& Taylor, M. (2010). Over-indebtedness in Great Britain: An analysis using the wealth and assets survey and household annual debtors survey (Issue October). Crown. 